\title{
Phytophthora nicotianae: Agente Etiológico da Gomose da Acácia-Negra no Brasil
}

\author{
Álvaro F. dos Santos ${ }^{1 *}$, Edna Dora. M. N. Luz ${ }^{2 *} \&$ Jorge Teodoro de Souza ${ }^{2}$ \\ 'Embrapa Florestas, Cx. Postal 319, CEP 83411-000, Colombo, PR, e-mail: alvaro@cnpf.embrapa.br; \\ ${ }^{2}$ CEPLAC/CEPEC/SEFIT, Cx. Postal 07, CEP 45600-970, Ilhéus, BA
}

(Aceito para publicação em 31/08/2004)

Autor para correspondência: Álvaro F. dos Santos

SANTOS, A.F. DOS, LUZ, E.D.M.N. \& SOUZA, J.T. DE Phytophthora nicotianae: agente etiológico da gomose da acácianegra no Brasil. Fitopatologia Brasileira 30:81-84. 2005.

\section{RESUMO}

A gomose, causada por Phytophthora sp., é a mais importante enfermidade da acácia-negra (Acacia mearnsii) no Rio Grande do Sul, Brasil. A identificação específica permanecia indeterminada. Procurou-se, então, identificar a espécie de Phytophthora causadora desta doença no Rio Grande do Sul, usando características fisiomorfológicas e estudos moleculares baseados no seqüenciamento das regiões de Internal Transcribed Spacer (ITS). A patogenicidade dos isolados estudados para a acácia-negra foi confirmada. Os estudos confirmaram Phytophthora nicotianae como a correta identidade dos isolados fitopatogênicos. Este é o primeiro relato de P. nicotianae em acácia-negra no Brasil.

Palavras-chave adicionais: Acacoa mearnsii, patogenicidade, isolado fitopatogênico

\begin{abstract}
Phytophthora nicotianae: causal agent of gummosis of black wattle in Brazil

Gummosis caused by Phytophthora sp. is the most important disease of black wattle (Acacia mearnsii) in Rio Grande do Sul, Brazil. Isolates of Phytophthora sp. associated with diseased plants were obtained from Rio Grande do Sul and their pathogenicity was confirmed. In order to elucidate the correct identity of the fungus at the species level physiomorphological characteristics were determined and molecular studies were conducted based on sequences of Internal Transcribed Spacer (ITS) region. The fungus was identified as Phytophthora. nicotianae. This is the first report of $P$. nicotianae on black wattle in Brazil.
\end{abstract}

Additional keywords: Acacoa mearnsii, patogenicity, patogenic isolate.

A acácia-negra (Acacia mearnsii De Wild.) é uma espécie florestal originária da Austrália, plantada em diversos países, tendo sido introduzida no Brasil, no Estado do Rio Grande do Sul, na década de 30. Atualmente, com uma área plantada superior a 150.000 ha, compõe um dos maciços florestais daquele Estado. A contribuição dessa planta aos mais variados segmentos econômicos e industriais é ampla, tanto para a extração do tanino, a partir da casca, como para o uso da madeira, na produção de energia, celulose, papel e chapa de fibra. No Brasil, é plantada principalmente para a produção de tanino (Fleig, 1993).

A gomose, doença do tronco causada por Phytophthora sp., é o principal problema sanitário da acácianegra e ocorre nas principais regiões produtoras do Brasil e da África do Sul (Santos et al., 1998). No Brasil, encontra-se distribuída em grande parte das áreas produtoras do Rio Grande do Sul. Essa doença danifica a casca, principalmente nas porções basal e mediana do tronco (Figura 1), chegando a causar prejuízos econômicos pela diminuição no aproveitamento da casca e, em casos mais extremos, pela morte das árvores. Em plantios comerciais em idade de corte (sete anos) chega a atingir 23\% de indivíduos (Sotta et al., 1994). A

* Bolsistas do CNPq identificação específica do patógeno permanecia indeterminada. Este trabalho teve o objetivo de identificar a espécie de Phytophthora, causadora da gomose da acácianegra no Brasil, usando características fisiomorfológicas e estudos moleculares baseados no seqüenciamento das regiões de Internal Transcribed Spacer (ITS).

Amostras da casca do tronco de árvores com sintomas de gomose foram coletados, em plantações localizadas nos municípios de Encruzilhada do Sul, Cristal e Piratini, no Rio Grande do Sul. Para o isolamento, utilizou-se o meio ágar-água $2 \%$ suplementado com ampicilina (50 ppm), benomil (10 ppm) e cloramfenicol (20 ppm) (Santos et al., 1998). As placas foram incubadas no escuro, a $25^{\circ} \mathrm{C}$. Micélio com características do gênero Phytophthora crescendo a partir dos tecidos doentes foram tranferidos para o meio BDA (200 $\mathrm{g}$ de batata, $20 \mathrm{~g}$ de dextrose, $18 \mathrm{~g}$ de ágar e $1.000 \mathrm{ml}$ de água destilada) e conservados neste meio de cultura, por meio de repicagens periódicas. Procedeu-se, então, as avaliações das características morfo-físiológicas dos isolados, que foram denominados AN 3, AN 8 e AN 16. Para a identificação foram usadas as chaves de Waterhouse (1963), Waterhouse (1970), Neehook et al. (1978) e Stamps et al. (1990), além de Erwin \& Ribeiro (1996) e Frezzi (1950). 
A.L. Santos et al.

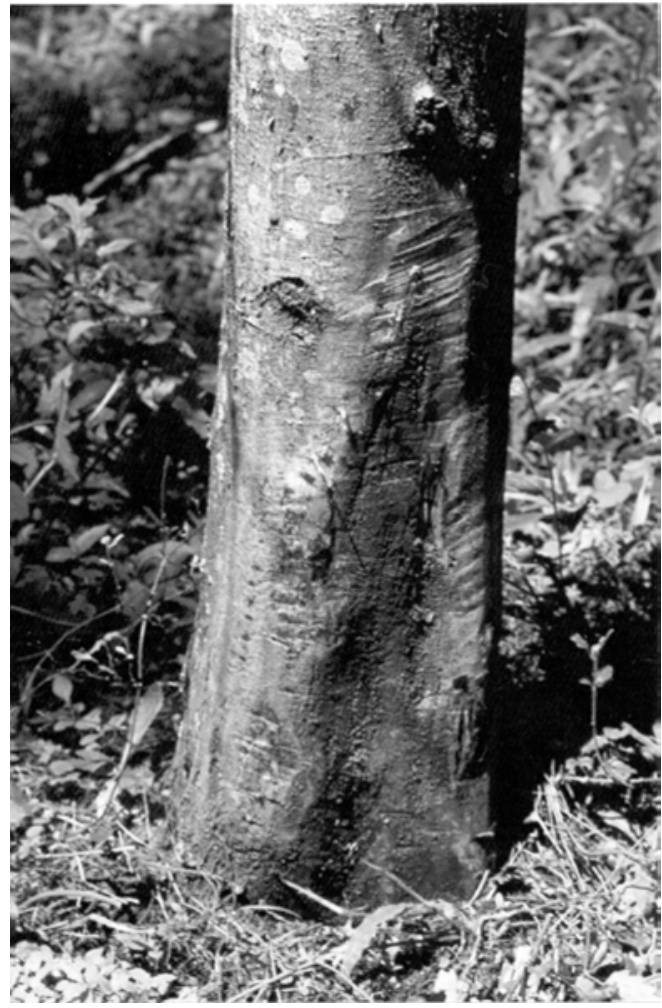

FIG. 1 - Sintoma da gomose em tronco de acácia-negra (Acacia mearnsii)

Para estudar o tipo de colônia, foram usados os meios BDA, cenoura-ágar (CA), fubá ágar (CMA) e V8-ágar. Como os isolados produziram poucos esporângios nesses meios de cultura utilizou-se então, para estimular a produção de esporângios, solução de $\mathrm{KNO}_{3}$ (Ribeiro, 1978), conforme segue: os isolados de Phytophthora sp. foram crescidos em meio CA, incubados no escuro contínuo por sete dias. Após este período, o meio de cultura contendo micélio fúngico foi cortado em tiras paralelas de aproximadamente $4 \mathrm{~mm}$ de largura. Em seguida, as tiras foram transferidas para placas de Petri esterilizadas e distribuídas de maneira que ficassem cerca de meio centímetro distanciadas entre si. Foi adicionada solução de $\mathrm{KNO} 3$, $\mathrm{pH}=6,0,001 \mathrm{M}$, em quantidade suficiente para deixar as tiras de meio de cultura com micélio fúngico submergidas. $\mathrm{O}$ conjunto foi distribuído em prateleiras e submetido à iluminação constante, fornecida por lâmpadas fluorescentes (General Eletric, 40 Watts, luz do dia), a cerca de $40 \mathrm{~cm}$ de altura (2000 lux), por um período de dez dias. Para as determinações biométricas dos esporângios, foram preparadas lâminas para microscopia coletando-se um pouco da massa micelial contendo esporângios e ou clamidósporos em lactofenol. As medidas foram feitas em 50 unidades de cada um dos tipos de esporos.

Para determinar o grupo de compatibilidade, as culturas foram pareadas individualmente com os tipos padrões A1 (Phytophthora capsici Leonian) e A2 [P. palmivora (Butler) Butler], do cacaueiro (Theobroma cacao L.), da coleção da
CEPLAC, Ilhéus-BA, em meio CA, no escuro a $25^{\circ} \mathrm{C}$. Avaliouse a formação de oósporos a partir do sexto dia de incubação.

Foram testados os efeitos de diferentes temperaturas $\left(8,12,16,20,24,28,32,35^{\circ} \mathrm{C}\right.$ ou $\left.36^{\circ} \mathrm{C}\right)$ e de três meios de cultura (BDA, CA e V8-ágar) sobre o crescimento micelial dos isolados de Phytophthora sp. O crescimento radial de colônias de cada isolado foi medido diariamente por sete dias ou até atingir a borda da placa.

O teste de patogenicidade foi realizado em mudas de acácia-negra com dez meses de idade, conforme segue: na inoculação retirou-se do caule, um disco de casca de $7 \mathrm{~mm}$ de diâmetro, a uma altura de $5 \mathrm{~cm}$ do solo e, em seguida, colocouse um disco de $7 \mathrm{~mm}$ de diâmetro de meio BDA, contendo micélio do fungo, que tinha sido previamente incubado no escuro à temperatura de $24{ }^{\circ} \mathrm{C}$, por sete dias. $\mathrm{O}$ local foi envolto com fita adesiva. Foram inoculadas dez plantas para cada isolado. A testemunha consistiu em se colocar um disco de BDA sem o fungo. A avaliação foi realizada após 45 dias de incubação, determinando-se o tamanho da lesão e a presença de exsudação de goma. Os fragmentos dos tecidos de casca obtidos a partir das margens das lesões foram usados para o reisolamento do fungo.

Para extração do DNA a massa micelial de cada um dos isolados (AN 3, AN 8 e AN 16) foi produzida em placas de Petri contendo o meio líquido de batata-dextrose. O DNA genômico de cada isolado foi extraído a partir de aproximadamente 250 mg de massa micelial, utilizando-se o método do SDS com algumas modificações: o micélio foi macerado em cadinho de porcelana em contato com $\mathrm{N}_{2}$ líquido. Em seguida, o macerado foi colocado em um tubo plástico de $1,5 \mathrm{ml}$, ao qual foram adicionados $700 \mu \mathrm{l}$ de tampão de lise constituído por Tris- $\mathrm{HCl}$ 200 mM, pH 8,0, EDTA 25 mM, dodecil sulfato de sódio 1\%, $\mathrm{NaCl} 250$ mM e 2-mercaptoetanol 1\%. O macerado foi misturado ao tampão de lise e os tubos mantidos em banho-maria $\left(70{ }^{\circ} \mathrm{C}\right)$ por uma hora, sendo agitados, a cada 10 min. Após a incubação, foi realizada a desproteinização, adicionando-se $600 \mu \mathrm{l}$ de clorofórmio-álcool isoamílico $(24: 1 \mathrm{v} / \mathrm{v})$. Em seguida, as amostras foram agitadas, por suaves inversões, por $10 \mathrm{~min}$ e centrifugadas a $4^{\circ} \mathrm{C}$, a $18.845 \mathrm{~g}$, por $10 \mathrm{~min}$. O sobrenadante de cada amostra foi transferido para tubos de 1,5 ml limpos e o processo de desproteinização foi repetido. Para a precipitação do DNA, foi adicionado ao sobrenadante final, 1/10 do seu volume de acetato de sódio $3 \mathrm{M}, \mathrm{pH} 5,2$ e 2/3 de isopropanol gelado. Os tubos foram mantidos a $-20^{\circ} \mathrm{C}$ por $2 \mathrm{~h}$ e, a seguir, centrifugados como anteriormente. O sobrenadante foi descartado e o precipitado lavado duas vezes com etanol $70 \%$ (v/v) e seco à temperatura ambiente. Posteriormente, os ácidos nucléicos totais foram ressuspendidos em $150 \mu \mathrm{l}$ de água contendo RNAse na concentração de $40 \mu \mathrm{g} / \mathrm{ml}$ e colocados em banho-maria a $37{ }^{\circ} \mathrm{C}$ para a completa ressuspensão. Após esse período, o DNA foi novamente precipitado, centrifugado e ressuspendido em $100 \mu \mathrm{l}$ de água, como já descrito.

A quantidade do DNA foi estimada por espectrofotometria a $260 \mathrm{~nm}$ e a relação $\mathrm{A}_{260} / \mathrm{A}_{280}$ foi utilizada para avaliar a pureza do DNA. Bandas de DNA genômico total, separadas por eletroforese em gel de agarose $0,8 \%$, foram 
usadas como indicadoras da integridade do DNA extraído. Após esse processo, as amostras de DNA foram diluídas para $10 \mathrm{ng} / \mu \mathrm{l}$.

Os primers ITS1 e ITS4 descritos por White et al. (1990) foram usados na amplificação do fragmento de rDNA incluindo ITS 1, o gene 5,8 S do DNA ribossomal e ITS2 através da reação de cadeia de polimerase (PCR). As amplificações de PCR foram realizadas em reação a $25-\mu 1$ contendo $30 \mathrm{ng}$ de DNA, 1X PCR tampão (Invitrogen), $1.5 \mathrm{mM} \mathrm{MgCl}_{2}$ (Invitrogen), $200 \mu \mathrm{M}$ de dATP, dCTP, dGTP, and dTTP (Promega), $40 \mathrm{pmol}$ de cada primer, e $2.0 \mathrm{U}$ de Taq polimerase (Invitrogen). O programa de $\mathrm{PCR}$ consistiu de uma desnaturalização inicial de 5 min a $95^{\circ} \mathrm{C}$, seguida de 35 ciclos de $1 \min$ a $94^{\circ} \mathrm{C}, 2$ min a $55^{\circ} \mathrm{C}$, e 3 min a $72^{\circ} \mathrm{C}$, com uma final de 5 min a $72^{\circ} \mathrm{C} \mathrm{em}$ termociclador MJ Research PTC-200. Alíquotas de $5 \mu 1$ foram separadas em gel de agarose a 1\% (peso/vol) em tampão 1 X TAE ( 40 mM Tris, 20 mM ácido acético, 1 mMEDTA [pH 8]), corado com ethidium bromide, e fotografados por UV.

Antes do seqüenciamento, os produtos de PCR foram purificados com um kit QIAquick PCR (QIAGEN), de acordo com as especificações do fabricante. Cada isolado foi seqüenciado usando os primers ITS1 e ITS4. O seqüenciamento da região de rDNA incluindo os espaços ITS1, ITS2 e 5.8S rDNA, foi feito em seqüenciador automático de DNA com terminais florescentes usando um prisma seqüenciador $\mathrm{ABI}$ 377 (Applied Biosystems).

Para análise filogenética obteve-se através do GenBank as seqüências de Phytophthora nicotianae Breda de Haan 911 (A1) (AY208131), P. nicotianae UQ848 (AF266776), P. palmivora UQ1294 (AF266780), P. capsici21170 (AY251662), e P. citrophthora (Sm. \& Sm.) Leonian IMI209255 (L76536) que foram incluídas na árvore filogenética para efeito de comparação. A análise de BLASTN usando o programa CLUSTAL W 1.81 (Thompson et al., 1994) foi aplicada e estimadas as distancias de Pairwise com um modelo de diferenças numéricas usando o Mega2 (Kumar et al., 2001). A interpretação das interferências filogenéticas foi feita pelo método do vizinho mais próximo (Saitou \& Nei, 1987). Os locais que apresentavam falhas não foram considerados nas interferências filogenéticas.

Os dados biométricos apresentados referem-se às médias obtidas dos três isolados AN 3, AN 8 e AN 16. Os isolados de acácia-negra apresentaram o maior crescimento micelial entre $24 \mathrm{e} 32^{\circ} \mathrm{C}$ e nenhum crescimento a $36^{\circ} \mathrm{C}$ (Figura 2). As culturas, em meio CA eram petalóides, com bordas difusas, micélio aéreo denso e cotonoso. Os esporângios, formados em caldo de cenoura, eram papilados, persistentes, predominatemente ovóides (Figura 3B) a mais ou menos esféricos, medindo 33,3-56,0 X 24,5-35,0 $\mu \mathrm{m}$ (média: 42,5 x 29,6 $\mu \mathrm{m})$, com relação comprimento/largura de 1,4:1, profundidade média de papila de $4,0 \mu \mathrm{m}$ e poro com $6,0 \mu \mathrm{m}$ de largura. Os clamidósporos, presentes em CMA e em caldo de cenoura, apresentaram-se terminais (Figura 3A) ou intercalares, com diâmetro de 25,4 a 40,3 $\mu \mathrm{m}$ (média de $33 \mu \mathrm{m}$ ). As culturas são heterotálicas, com presença de isolados dos grupos de compatibilidade $\mathrm{A}_{1}$ e $\mathrm{A}_{2}$. Os oósporos mediram $23-38 \mu \mathrm{m}$ de diâmetro (média $29 \mu \mathrm{m}$ ). Os anterídios eram anfígenos.
Todos os isolados foram patogênicos à acácia-negra e formaram lesões nas plantas inoculadas, porém não se observou exsudação de goma nas lesões produzidas. As plantas testemunhas continuaram o seu desenvolvimento normal, sem lesões.

Baseado nas seqüências parciais de ITS 1 e ITS2, e no gene 5.8S do DNA ribossomal, os isolados apresentaram $100 \%$ de seqüências idênticas entre si e com os isolados do GenBank $911\left(\mathrm{~A}_{1}\right), 6134\left(\mathrm{~A}_{2}\right)$ e UQ848 de P. nicotianae.

Pelas características culturais e morfológicas, e pela análise filogenética baseada no seqüenciamento parcial de ITS 1 e ITS2, e no gene 5.8S do DNA ribossomal, os isolados de Phytophthora sp. obtidos de acácia-negra no Rio Grande do

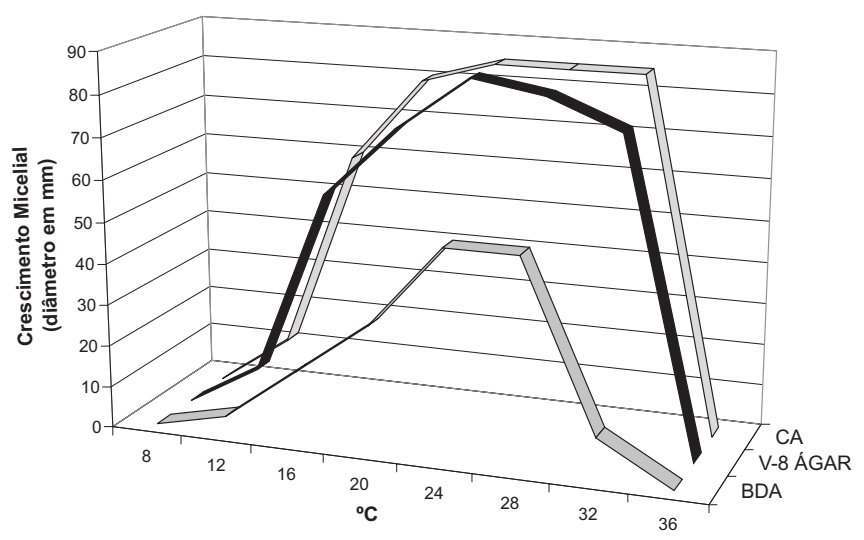

FIG. 2 - Efeito do meio de cultura e da temperatura no crescimento micelial de Phytophthora nicotianae.

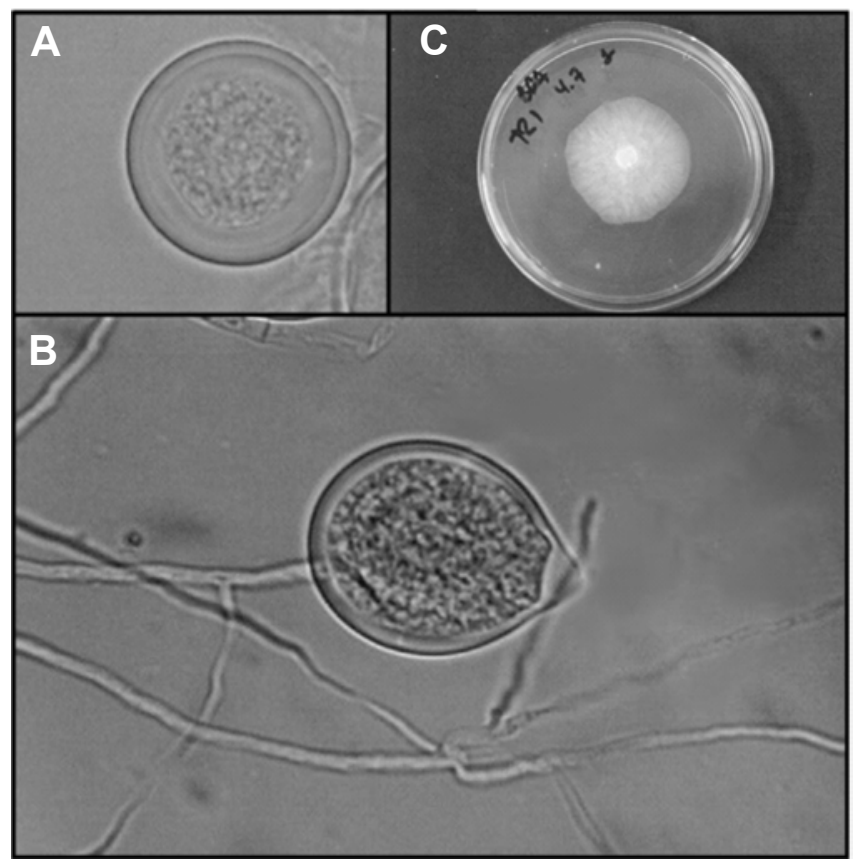

FIG. 3 - A: Clamidósporo; B: Esporângio; C: Cultura de Phytophthora nicotianae. 
A.L. Santos et al.

Sul foram enquadrados como pertencentes à espécie $P$. nicotianae, conforme segue: esporângios persistentes, papilados e ovóides; clamidósporos terminais ou intercalares; heterotálicos, formando anterídios anfígenos. Na África do Sul, Zeijlemaker (1971) e Roux \& Wingfield (1997) também associaram a gomose ao fungo $P$. nicotianae. Este trabalho constitui-se no primeiro relato de $P$. nicotianae em acácia-negra no Brasil.

\section{REFERÊNCIAS BIBLIOGRÁFICAS}

ERWIN, D.C. \& RIBEIRO, O.K. (Eds.) Phytophthora diseases worldwide. St. Paul, APS Press. 1996.

FLEIG, F.D. Análise econômica de sistema de produção com acácianegra (Acacia mearnsii De Wild.) no Rio Grande do Sul. (Tese Mestrado). Santa Maria:Universidade Federal de Santa Maria, 1993.

FREZZI, M.J. Las especies de "Phytophthora" en la Argentina. Revista de Investigaciones Agrícolas 4:47-134. 1950.

KUMAR, S., TAMURA, K., JAKOBSEN, I.B. \& NEI, M. MEGA 2:molecular evolutionary genetics analysis software. Bioinformatics Applications Note 17:1244-1245. 2001.

NEEHOOK, F.J., WATERHOUSE, G.M. \& STAMPS, D.J. Tabular key to the species of Phytophthora de Bary. Kew, Commonweath Mycological Institute. Mycology, Papers 143. 1978.

ROUX, J. \& WINGFIELD, M.J. Survey and virulence of fungi occurring on diseased Acacia mearnsii in South-Africa. Forest Ecology and Management 99:327-336. 1997.

SAITOU, N. \& NEI, M. The neigbor-joining method:a new method for reconstructing phylogenetic treess. Molecular Biology and Evolution 4:406-425. 1987.

SANTOS, A.F., AUER, C.G. \& GRIGOLETTI JR., A. Caracterização de tipos de gomose da acácia-negra (Acacia mearnsii) no sul do Brasil. Boletim de Pesquisa Florestal 37:31-40. 1998.

SOTTA, E.D., HIGA, A.R., LAVORANTI, O.J., STEIN, P.P. Avaliação dos danos causados pela gomose em acácia-negra. Curitiba:EMBRAPA-CNPF, 1994.

STAMPS, D.J., WATERHOUSE, G.M., NEEHOOK, F.J. \& HALL, G.S. Revised tabular key to the genus Phytophthora. Wallingford, CAB International Mycology Papers 162. 1990.

THOMPSON, J. D., HIGGINS, D.G. \& GIBSON, T.J. CLUSTAL W:improving the sensitiviy of progressive multiple alignment through sequence weighting, positions-specific gap penalties and weight matrix choice. Nucleic Acids Research 22:4673-4680. 1994.

WATERHOUSE, G. M. Key to the species of Phytophthora de Bary. Kew, Commonweath Mycological Institute. Mycology, Papers 92. 1963.

WATERHOUSE, G.M. The genus Phytophthora de Bary. Diagnoses (or descriptions) and figures from the original papers. Kew, Commonweath Mycological Institute. Mycology, Papers 122. 1970.

WHITE, T.J., BRUNS, T., LEE, S. \& TAYLOR, J. Amplification and direct sequencing of fungal ribosomal RNA genes for phylogenetics. In: Innis, M. A., Gelfand, D.H., Sninsky, J.J. \& White, T.J. (Eds.)PCR Protocols:a guide to methods and appications. pp.315-322. Academic Press, San Diego. 1990.

ZEILJEMAKER, F.C.J. Black - butt disease of black wattle caused by Phytophthora nicotianae var. parasitica. Phytopathology 61:144145. 1971. 